\title{
Bio Farming Agrotechnologies: Inventive Challenges of Plant Sciences
}

\author{
Akbar Nikkhah* \\ Chief Highly Distinguished Professor, Department of Animal Sciences, Faculty of Agricultural Sciences, University of Zanjan, Zanjan, Iran \\ *Corresponding author: Akbar Nikkhah, Chief Highly Distinguished Professor, Department of Animal Sciences, Faculty of Agricultural Sciences, University of Zanjan, \\ Zanjan 313-45195, Iran, Tel: +98-241-5152801; Fax: +98-241-5283202; E-mail: anikkha@yahoo.com, nikkhah@znu.ac.ir
}

Rec date: Jul 09, 2014, Acc date: Jul 11, 2014, Pub date: Jul 13, 2014

Copyright: (c) 2014 Nikkhah A. This is an open-access article distributed under the terms of the Creative Commons Attribution License, which permits unrestricted use, distribution, and reproduction in any medium, provided the original author and source are credited.

\section{Editorial}

This editorial seeks to address new developments in bio farming agrotechnolgies as innovative postmodern challenges in plant sciences. Plant-origin biopharmaceuticals (BPC) are in the developing phase as the upcoming commercial states-of-the-art plant-human-animal biotechnologies. These may have highly effective production scale and economics, global safety, storage capacity, and reasonably efficient distribution. These proteins offer promising opportunities to synthesize and supply cost-effective medicines and vaccines. However, disadvantages include doubtful regulatory grounds in platform-raised crops, and vacillating manufacturing practice regulations in fieldgrown plants. The novel products must undergo vigilant cooperation and compromises of academic and commercial property landscape to be widely useable. Authorized operation licenses must be ensured for successful application and utilization in specific countries and regions. These products will enable saving life for humans and animals where environmental challenges concur.

Plant-derived platforms have rather low production and storage costs, low contamination risks, and reasonably high product quality and scale-up capacity, compared to mammalian cells, bacteria, yeast, and transgenic-animal based systems. Numerous platforms have been utilized to produce recombinant proteins (RP) from plants, such as leafy crops, cereal and legume seeds, oilseeds, fruits, vegetables, cell cultures, algae, and aquatic plants. Producing RP in seeds is important, as they are the evolutionary packages of storage proteins in a stable environment. As well, antibodies accumulate at high levels in seeds and remain functional for several years. Such effective storage is due to the desiccated nature of mature seeds. The rich combinations of molecular chaperones and disulfide isomerizes ensure appropriate protein folding in the expanding seeds, in absence of proteases. As a result of the limited size of seeds, their RPs are found in high concentrations, despite the lower yield than expected of bio massive leafy crops, such as tobacco and alfalfa. This property is beneficial for extraction and downstream processing [1-3]. The relatively simple seed proteome (less competing proteins) along with low levels of the substances known to interfere with downstream processing steps (e.g., phenolics and alkaloids in tobacco leaves and oxalic acids in alfalfa) facilitate processing. Oil drops in safflower and rapeseed are additional advantages and can be exploited during the initial purification stages. Moreover, seed proteins do not usually interfere with plant growth, which limits adventitious contact with non-target organisms, such as biosphere microbes and leaf-consuming herbivores [4].

Most recently, progress has been made in development of plantmade vaccines for veterinary purposes. Enterotoxigenic Escherichia Coli can cause a variety of diseases in livestock, including Newcastle disease, foot-and-mouth disease, and diarrheal diseases. Appropriate plant production platforms are being developed for plant species and processing and transformation technologies in producing widely effective and well-preserved vaccines. However, envirocommercial challenges are to be overcome before such vaccines may gain legislative approvals for regional and continental uses [5].

Molecular farming is the plant-based production of commercial biopharmaceutical recombinant proteins. Plants can be engineered using a multitude of methods including nuclear transformation, plastid engineering, viral based transient expression, agro infiltration, and magnifection techniques. Such cultures act as more effective, minimally-perishable, and economical vehicles and platforms for protein and vaccine production. A variety of grain legumes have been used to express RPs. However, two species of pea and soybean have been the generally explored production hosts. Despite a relatively low annual grain yield than cereals of mainly maize and rice, soybean's main advantage is its high seed protein content. However, soybean's transformation procedures are time-consuming. Limited molecular soybean farmings are reported. A humanized antibody produced against herpes simplex virus may be conducted in the plant rather than seeds alone [6,7]. Casein has been expressed in soybean seeds using a lectin expression cassette. Another practical possible issue with soybean is its abundant oil content that might interfere with downstream processing steps.

Pea is similar to soybean in annual grain yield and seed protein. As a result, pea is regarded as a suitable platform for reasonably high RP yields per hectare. However, pea costs could be approximately $50 \%$ more than soybeans, thus requiring greater seed yield to make pea a viable agrotechnological plant. The major pharmaceutical proteins expressed in peas include single-chain antibodies. An example is an antibody expressed at low levels to act against a cancer antigen as controlled by a seed-specific legumin A promoter. Another is an antibody expressed under 'unknown seed proteins' (USP) promoter, reaching $2 \%$ of total seed proteins $[8,9]$.

The emerging biotechnologies of mainly plant-origin and legumederived pharmaceutical proteins production encounter real challenges. Agrotechnologists and supporting sciences and industries should convince lawmaking and ethical organizations and investing companies that new innovative agrotechnologies in plant biofarming are safe, economical, and viable. The human vaccine agrotechnology can become feasible based on technical merits and approvals from public and social sectors. Future research on optimizing special genes expression is a must. That will ensure how and if transgenic plant vaccines meet quality standards in terms of purity, potency, safety, and efficacy as far as the World Health Organization is concerned.

\section{Acknowledgments}

'The Ministry of Science, Research and Technology' and 'University of Zanjan' are thankfully acknowledged for supporting the author's global programs of optimizing the new millennium science edification. 
Citation: Nikkhah A (2014) Bio Farming Agrotechnologies: Inventive Challenges of Plant Sciences. Agrotechnol 2: e110. doi:

Page 2 of 2

\section{References}

1. Nikkhah A (2014) On Alfalfa Bioengineering of Humans, Plants and Animals: The Tool and The Target. Aus J. Biengin. Biotechnol. In Press.

2. Nikkhah A (2013) Legumes Biofarming and Biopharmaceutical Sciences: A Review Res J Medicin Plant 6: 466-488.

3. Nikkhah A (2012) Legume Biotechnopharmaceutics. LAP LAMBERT Publishing GmbH \& Co. KG, Germany, ISBN 978-3-8473-4025-6.

4. Ma JK, Chikwamba R, Sparrow P, Fischer R, Mahoney R, et al. (2005) Plant-derived pharmaceuticals--the road forward. Trends Plant Sci 10 580-585.

5. Twyman RM, Schillberg S, Fischer R (2005) Transgenic plants in the biopharmaceutical market. Expert Opin Emerg Drugs 10: 185-218.
6. Twyman RM, Stoger E, Schillberg S, Christou P, Fischer R (2003) Molecular farming in plants: host systems and expression technology. Trends Biotechnol 21: 570-578.

7. Fischer R, Stoger E, Schillberg S, Christou P, Twyman RM (2004) Plantbased production of biopharmaceuticals. Curr Opin Plant Biol 7: 152-158.

8. Ling HY, Pelosi A, Walmsley AM (2010) Current status of plant-made vaccines for veterinary purposes. Expert Rev Vaccines 9: 971-982.

9. Sunil Kumar GB, Ganapathi TR, Srinivas L (2007) Bapat, Plant molecular farming: host systems, technology and products, In Application of Plant Metabolic Engineering. Spinger Publ: 45-77. 